\title{
Global Climate Socialism (GCS)
}

\author{
Nils-Axel Mörner \\ Correspondence: Nils-Axel Mörner, Paleogeophysics \& Geodynamics, Stockholm, Sweden. E-mail: morner@pog.nu
}

Received: November 5, 2018

doi:10.11114/smc.v6i2.3873
Accepted: December 9, 2018

Online Published: December 11, 2018

URL: https://doi.org/10.11114/smc.v6i2.3873

\begin{abstract}
Climate has always changed, and will always change. The present global warming (1970-2000) is real, but driven by natural forces (NGW) not anthropogenic (CO2) forces (AGW). Observational facts and physical laws set the frames of what is possible, and what must be discarded as nonsense. Despite this the IPCC concept of AGW forcing has gained remarkable international recognition; not because of its own merits but thanks to a very effective lobbying campaign. It has rather taken the form of a new world order with obeying, paying and silence in the center, all strong signs of the establishment of a global climatic socialism system.
\end{abstract}

Keywords: global warming, solar forcing, natural global warming (NGW), not anthropogenic (AGW), IPCC monopolization leading to Global Climate Socialism

\section{Introduction}

Earth's climate is controlled by factors that never remains constant, on the contrary they always change; generally cyclically but sometimes also as a new pulse. In recent time, very much focus has been put on climate change, and under the name of "global warming", it has been claimed to be something new and unusual. The fact, however, is that it is by no means unique; neither in rate nor amplitude.

The increase in atmospheric $\mathrm{CO} 2$ from the burning of coal, lignite and petroleum has been proposed to cause an increase in global temperature: the so-called "global warming". Because this post-industrial-revolution burning was a human act, it has been called "anthropogenic global warming" (AGW).

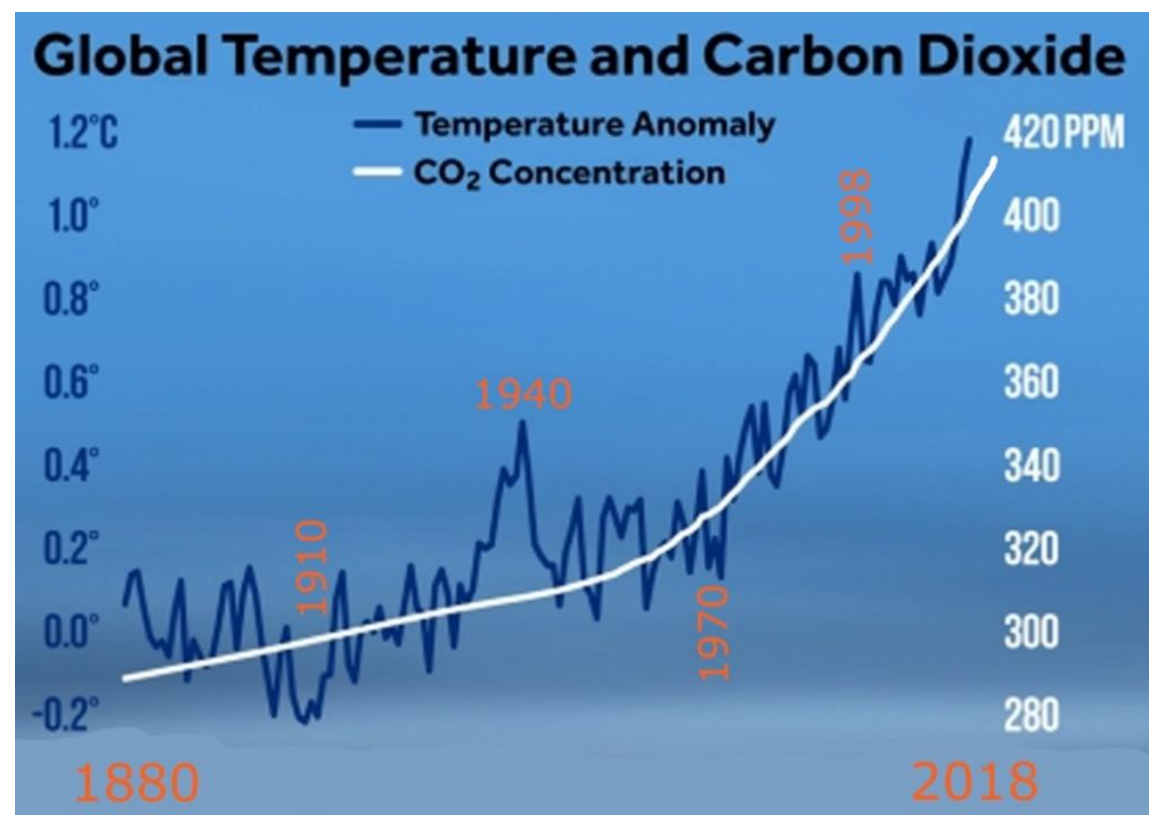

Fig. 1. This diagram (modified from Climate Central, 2017) was claimed to manifest a correlation between global temperature and atmospheric $\mathrm{CO} 2$ content. It is illusive, however, and based on a deformation of the temperature record. The high peak in the 1930s was as warm as today's values. For the last 18 years, there has virtually been a temperature

pause. 
As some sort of manifestation of a temperature/CO2 correlation, it became customary to show diagrams like Fig. 1. There is a problem, however: the temperature curve is not measured, but purposely deformed to achieve some sort of imaginary correlation.

\section{Results}

Real, measured, temperature values are quite different (Fig. 2). The proposed correlation between temperature and CO2 is gone. Instead something quite new has emerged (Mörner, 2018a): a clear 60-yr cycle. Furthermore, the 1910-1940 years rise in temperature is as big as the 1970-2000 rise, and there is no way the first rise could have been CO2-forced. Therefore, the Fig. 2 graph is in direct opposition to CO2-forcing. Instead we must seek a solar forcing.

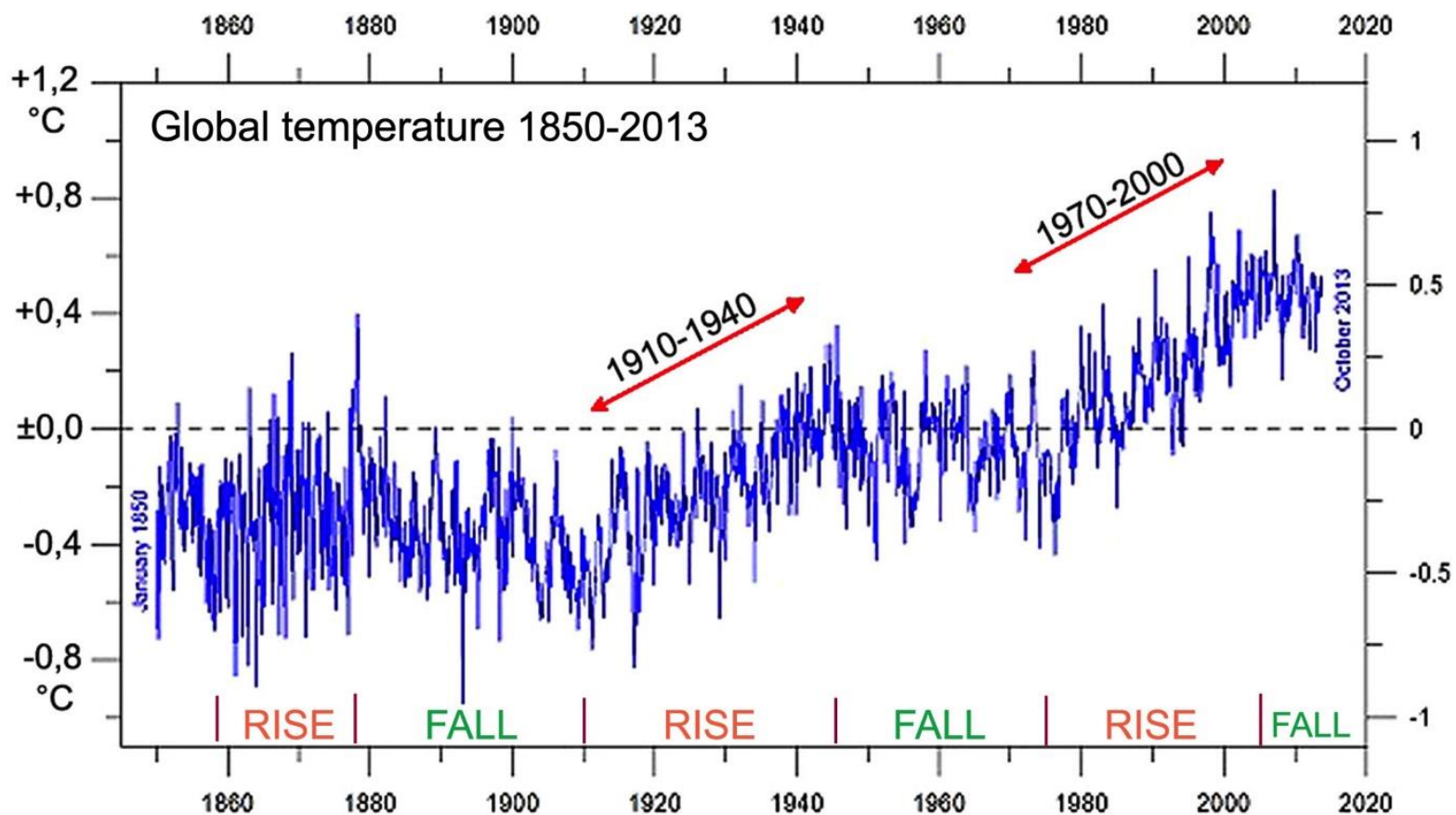

Fig. 2. Real changes in temperature (Humlum, 2013, 2018) documenting an absence of correlations with CO2 (as proposed in Fig. 1) but instead clear cyclic changes in global temperature of about 60 years during the last 170 years, providing a manifestation of the NGW concept and solar forcing (from Mörner, 2018a)

The 60-yr cycle implies evidence of a planetary-solar forcing (e.g. Scafetta, 2012; Mörner, 2015a; Gervais, 2016). This cycle was first defined in terrestrial climate data (Schlesinger \& Ramankutty, 1994), then in Earth's rotational data as a function of Solar Wind forcing (Mörner, 1996), and then in orbital forcing by Jupiter (Scafetta, 2012). The mode of planetary beat on the Sun, the Earth and the Earth-Moon system is discussed by Mörner (2015a, 2018b).

Whilst Fig. 1 was construction in order to give an impression of a correlation between global temperature and CO2 content (i.e. the AGW concept), Fig. 2 reveals that this is just an illusion, and that real temperature data give evidence of a planetary-solar forcing (i.e. the NGW concept) dominated by the 60 -yr cycle.

In normal scientific questions this would be enough to discard the AGW idea, and elevate the solar forcing as the dominant natural forcing function (NGW). But not in this case, because the AGW-hypothesis had been incorporated as the core issue in the Intergovernmental Panel of Climate Change (IPCC) as further discussed in Mörner (2018a) and (2007).

This project was proposed by Bert Bolin, driven by Olof Palme and launched by Gro Harlem Brundtland (Mörner, 2018a). It became a project under United Nations (Fig. 3), and even received the Nobel Peace Prize in 2009. By that, it could no longer be stopped by arguments and scientific facts. The means were scaremongering. The effects were climate hysteria and the end of an open scientific debate. "Science is settled2, they proclaimed, though the opposite was really the case. "97\% of the scientist agree with us", IPCC stated, though this was certainly not the case. Media seems to live on disasters and threats; the worse, the better.

And still, all the predictions of rapidly approaching disasters by the IPCC and its proponents have badly failed. All the 1196 atolls of the Maldives were in 1988 said to be under water in 30 years: that is this year and all the islands remain and sea level is not at all in a rapidly rising mode (Mörner et al. 2004; Mörner, 2007, 2011). In 2005, the UN Environmental Program predicted that climate change would create "50 million climate refugees by 2010 ". This is nothing but serious and unethical disinformation, because not yet have we seen any true "climate refugee". In 2007, Al 
Gore claimed that all the ice in the Arctic would be gone by 2013. Today, the ice volume is around $6.8 \times 10^{3} \mathrm{~km}^{3}$ (the Danish Meteorological Institute). The polar bears were claimed to suffer badly and to be threatened of extinction. But there have never been more of them, which give evidence of good conditions. Hurricanes is a part of the weather system; whilst the IPCC group claims they are becoming more frequent and severe, long-term statistics rather show a weak decrease to the present. Almost every day, do we hear media claims of this type, which are nothing but scaremongering and fake news.

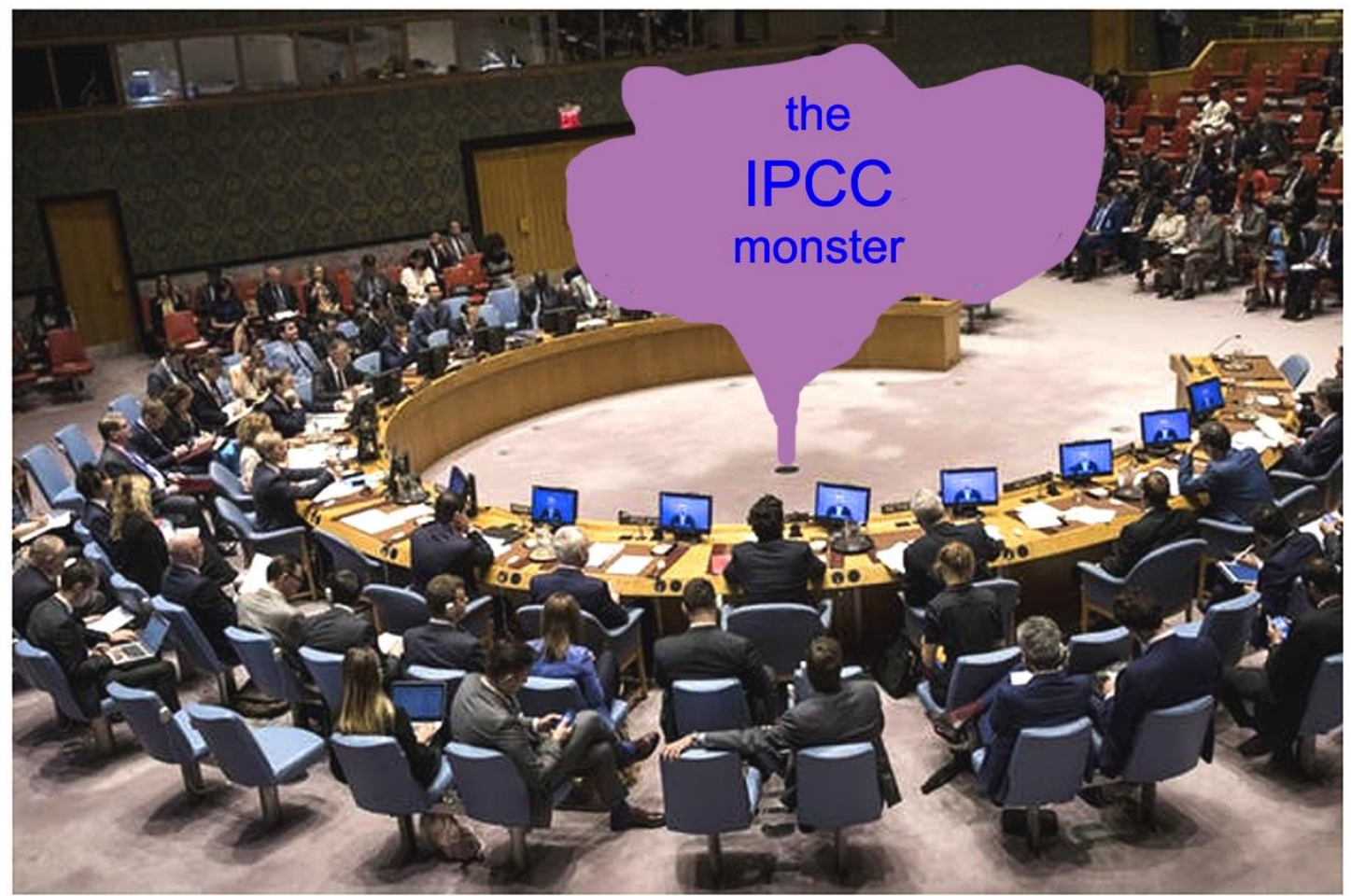

Fig. 3. The UN General Assembly enchanted by the IPCC Monster, demanding all to agree, believe and pay, to which they al bow and say "yes, we do". A similar "falling flat" attitude was demonstrated by the European Union Assembly

The UN General Assembly like the European Union Assembly act as bewitched (Fig. 3). This is totally incomprehensible, and we must all ask us: Why or How come?

We know how it all began. Bert Bolin formulating an idea of CO2-driven climate change, Olof Palme adopting the idea as means of leaving oil-dependence and rapidly to move in to nuclear power in an intergovernmental project, and finally Gro Harlem Brundtland proposing the IPCC project in 1988, which was immediately implemented with Bert Bolin as president and with the mission to prove the anthropogenic global warming (Mörner, 2018a). This fitted Margaret Thatcher perfectly well in her wishes to degrade the British coal industry. There seems to have been strong pushes from the Rockefeller foundations (Nordangård, 2012) probably both on Palme and Brundtland. With the well-orchestrated Nobel Peace Prize in 2009, the IPCC project of UN became very strong, nearly untouchable.

It soon took nearly religious dimensions, demanding obedience, believe and payment - and all what science stands for was gone, dogmas were put in the center, and those not obeying were exposed for inquisition's like treatment. Scientific journals were closed down (Mörner, 2015b) or put on the list of so-called predatory journals, but leaving journals "high-jacked" for their own purpose open for pal-reviewing, and refusal even to considering papers of non-conformist views (Mörner, 2018c).

At the same time as the IPCC continues to talk about climate and the need of reducing $\mathrm{CO} 2$ emission, the whole meaning of the IPCC project has become transformed and assimilated in the creation of a New World Order. 


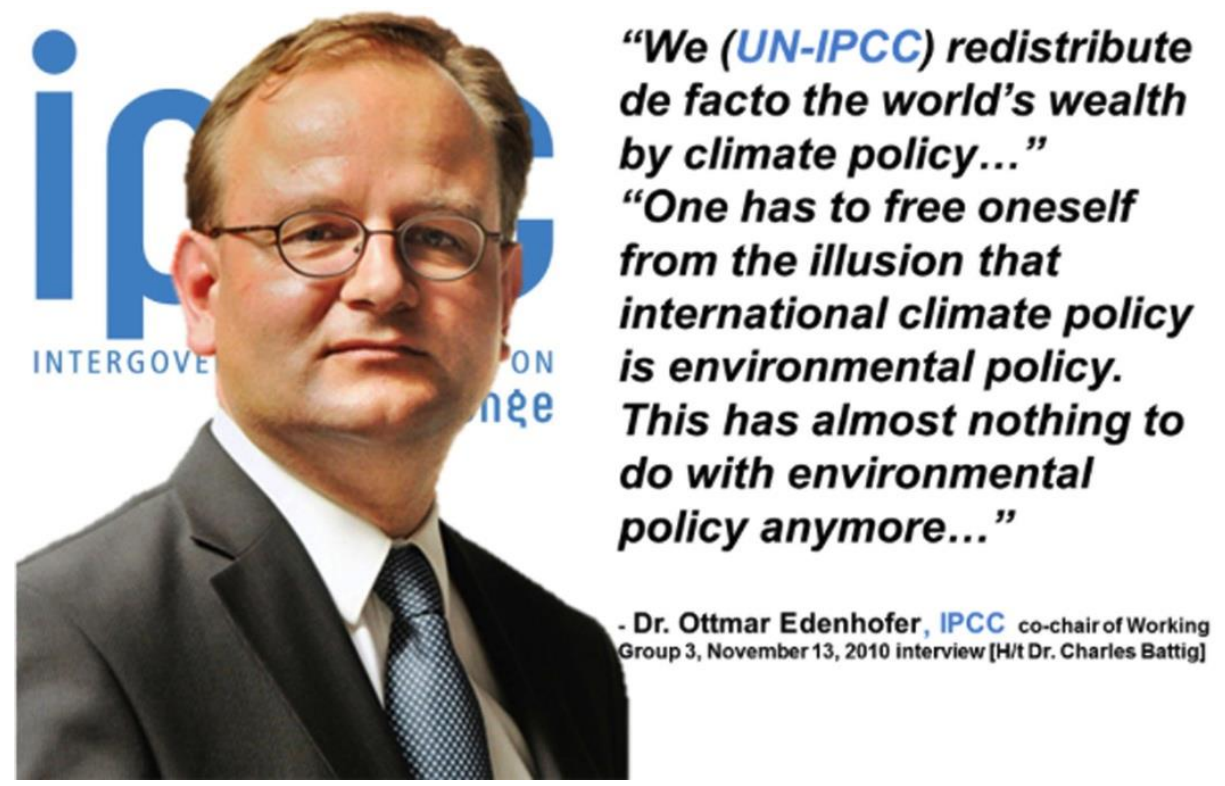

Fig. 4. In 2010 Dr. Edenhofer of the IPCC organization spoke up and we were informed that IPCC was not at all about climate change, but about the world order (Edenhofer, 2010).

At the G77 top-meeting in Bolivia in 2014 (with persons like Ban Ki-Moon, Al Gore and David Rockefeller present) the creation of a New World Order (NWO) was in focus and spelled out in the conference declaration. This was interpreted by the President of Venezuela, Nicolás Maduro, in terms of: "the capitalism must be demolished".

\section{A New World Order}

In 2013, Joe Biden, Vice-President of the United States gave a speech (Biden, 2013) where he said: "The task is to create a new world order" and the need of "one world government" (Fig. 5).

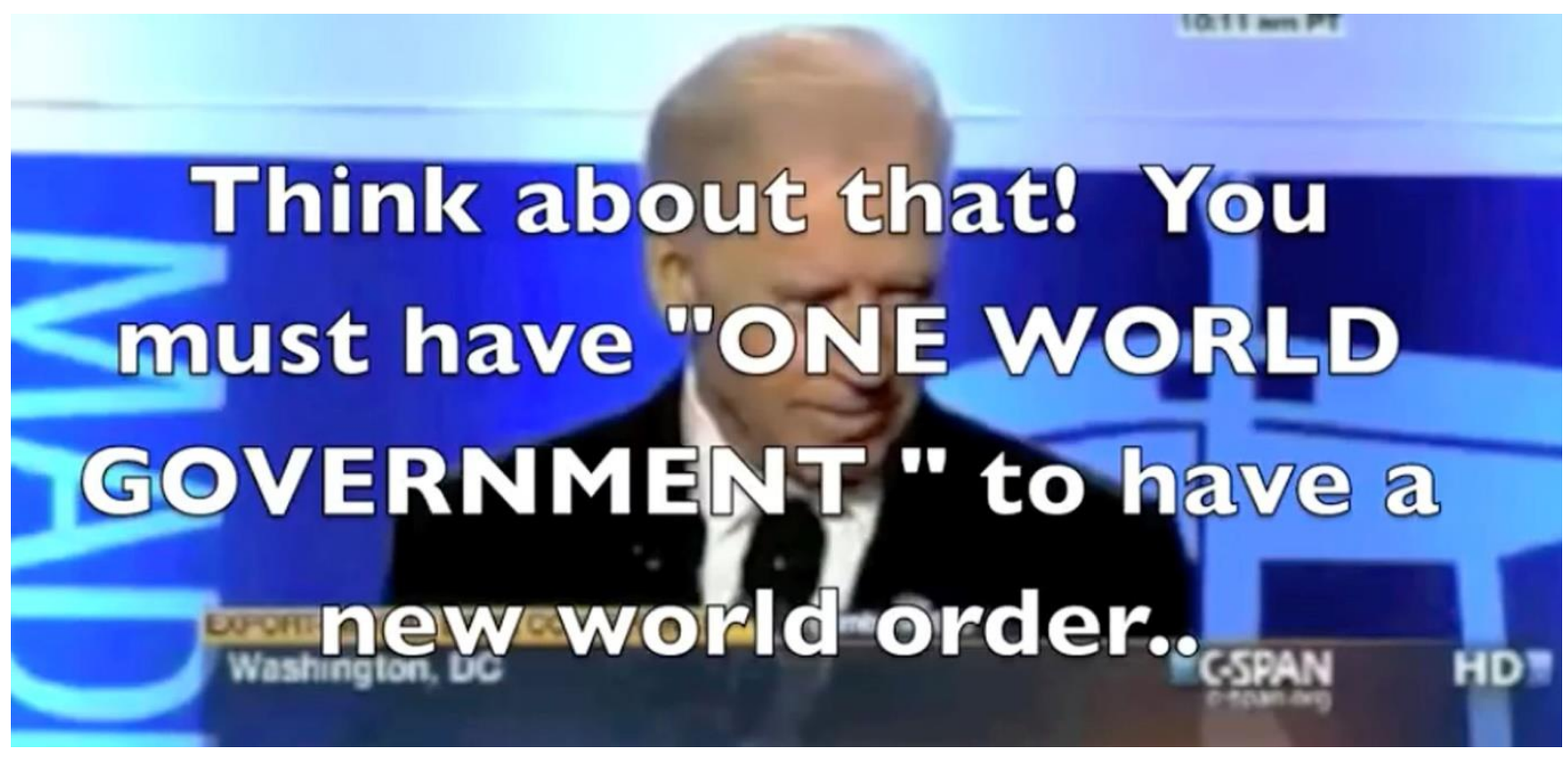

Fig. 5. Vice-President Joe Biden speaks in Washington DC on April 5, 2013

Sic transit gloria mundi (so all the glory of the world perishes): a climate project is high-jacked by global economical interests. "Fighting poverty", the World Bank earlier said. Now they say: "fighting climate change", and now climate change is a new world order.

The United Nation's stealthy ambitions to push for a New World Order will become manifested at the COP24 meeting in Poland (December 3-14, 2018) where the Paris Agreement is supposed to be transformed from its current non-legally-binding form into a full-blown UN treaty that ties its members into targets for reducing carbon dioxide emissions and into huge future financial obligations; i.e. the beginning of the New World Order. It seems, however, that 
we are rather facing a new religion demanding total obedience, believe without questioning and endless payment.

The $\mathrm{CO} 2$ molecule is certainly not a pollutant: it is the gas of life. Restrictions in emission of $\mathrm{CO} 2$ will have virtually no effect on climate, and is hence meaningless. But it has become a very effective way in the demand of obedience and believe, where we have to give up the normal questioning and observational facts (Mörner, 2018a, 2018c, 2018d).

\section{Global Climate Socialism}

All the scaremongering of disastrous effects of AGW does not scare me a bit. What scares me, however, is this now order of obedience, believe and payment. This is nothing but a new order of Global Climate Socialism (GCS). No doubt, inquisition has started, and all of us - and we are thousands and thousands of well-established scientists and normal questioning people - questioning IPCC statements are facing problems and acts of retaliation.

The salvation lies in science itself: the searching for new solutions and the questioning of so-called established ideas. Don't listen to the false prophets (Jer. 9:10), never give up the freedom of opinion, and always search for new connections and solutions. This is the true spirit of creative science.

Creationism is the provocative denying of biological evolution by giving up questioning and curiosity at the expense of totalitarian obedience and blind believe. Anthropogenic Global Warming (AGW) is as blind for science and education as creationism (Mörner, 2015a).

Finally, what was it Galileo Galileo said 400 years ago? - "No one should be scorned in physics disputes for not holding the opinions, which happens to please other people best" (Mörner, 2015b, p. 126).

\section{References}

Biden, J. (2013). Talk in Washington DC, April 5, 2013. http://www.nowtheendbegins.com/joe-biden-calls-for-a-new-world-order/

Climate Central (2017). Rising global temperature and CO2. http://www.climatecentral.org/gallery/graphics/co2-and-rising-global-temperatures

Edenhofer, O. (2010). Interview. https://www.nzz.ch/klimapolitik_verteilt_das_weltvermoegen_neu-1.8373227

Gervais, F. (2016). Anthropogenic CO2 warming challenged by 60-yr cycle. Earth-Science Reviews, 155, 129-135. https://doi.org/10.1016/j.earscirev.2016.02.005

https://www.researchgate.net/publication/283641399_Geoethics_the_principles_of_ethics_in_Natural_Sciences

Humlum, O. (2013). Kommentar til FNs klimapanels sammendrag. Report to Klimarealistene. http://www.klimarealistene.com

Humlum, O. (2018). Climater4you, September, 2018. Climate4you.com

Mörner, N. (1996). Global Change and interaction of Earth rotation, ocean circulation and paleoclimate, An. Brazilian Acad. Sc., 68(Supl. 1), 77-94. https://www.researchgate.net/publication/283971240

Mörner, N. A. (2007). The Greatest Lie Ever Told. P\&G-print, Stockholm, p. 1-20. ( ${ }^{\text {nd }}$ edition 2009, $3^{\text {rd }}$ edition 2010).

Mörner, N. A. (2011). The Maldives: A measure of sea level changes and sea level ethics. In: D.J. Easterbrook, Ed., Evidence-Based Climate Science, Elsevier, Chapter 7, 197-209. https://doi.org/10.1016/B978-0-12-385956-3.10007-5

Mörner, N. A. (2015a). Multiple Planetary Influences on the Earth. In: Mörner, N.-A., Ed., Planetary Influence on the Sun and the Earth, and a Modern Book-Burning, Nova Science Publishers, New York, Chapter 4, 39-50.

Mörner, N. A. (2015b). Planetary Influence on the Sun and the Earth, and a Modern Book-Burning, Nova Science Publishers, New York, Section B “A modern book-burning”, Chapters 11-16, 127-184.

Mörner, N. A. (2015c). Geoethics: the principles of ethics in Natural Sciences.

Mörner, N. A. (2018a). Anthropogenic Global Warming (AGW) or Natural Global Warming (NGW). Voice of the Publisher, 4, 51-59. https://doi.org/10.4236/vp.2018.44005

Mörner, N. A. (2018b). Planetary beat and sea level changes. In: Mörner, N.-A., Matlack-Klein, P. \& Assuncão Araújo, M., Eds, Basic Science of Climate Change, Porto Climate Conference 2018, The Conference Volume, p. 54-58. https://www.researchgate.net/publication/326882331 \& https://www.portoconference2018.org/

Mörner, N. A. (2018c). The illusive flooding of New York City. Nessa Journal of Environmental Sciences, 1(2), August 2018, Invited Paper.

Mörner, N. A. (2018d). Absolute evidence of the absence of an on-going sea level rise on Ouvéa Island of New 
Caledonia. SSRG International Journal of Geoinformatics and Geological Science, 5(3), 30-33.

Mörner, N. A., Tooley, M., \& Possnert, G. (2004). New Perspectives for the future of the Maldives. Global and Planetary Change, 40, 177-182.

Nordangård, J. (2012). Ordo ab Chao - Den politiska historien om biodrivmedel i den Europeiska Unionen. PhD-thesis, Linköping University, Electronic Press, 2012, 300.

http://liu.diva-portal.org/smash/record.jsf?pid=diva2\%3A572917\&dswid=343

Scafetta, N. (2012). A Shared Frequency Set between the Historical Mid-Latitude Aurora Records and the Global Surface Temperature. Journal of Atmospheric and Solar-Terrestrial Physics, 74, 145-163. https://doi.org/10.1016/j.jastp.2011.10.013

Schlesinger, M. E., \& Ramankutty, N. (1994). An Oscillation in the Global Climate System of Period 65-70 Years. Nature, 367, 723-726. https://doi.org/10.1038/367723a0

\section{Copyrights}

Copyright for this article is retained by the author(s), with first publication rights granted to the journal.

This is an open-access article distributed under the terms and conditions of the Creative Commons Attribution license which permits unrestricted use, distribution, and reproduction in any medium, provided the original work is properly cited. 